Supplement of Saf. Nucl. Waste Disposal, 1, 203-204, 2021

https://doi.org/10.5194/sand-1-203-2021-supplement

(C) Author(s) 2021. CC BY 4.0 License.

Supplement of

\title{
Application-oriented transdisciplinary basic research on nuclear waste management: hollow phrase or sensible concept?
}

Klaus-Jürgen Röhlig et al.

Correspondence to: Klaus-Jürgen Röhlig (klaus.roehlig@tu-clausthal.de)

The copyright of individual parts of the supplement might differ from the article licence. 


\section{i!i:.: TRANSENS}

TRANSDISCIPLINARY RESEARCH ON THE MANAGEMENT OF HIGH-LEVEL RADIOACTIVE WASTE IN GERMANY

Application-oriented transdisciplinary basic research on nuclear waste management: Hollow phrase or sensible concept?

Klaus-Jürgen Röhlig, Peter Hocke, Pius Krütli, René Martin, Ulrich Smeddinck

safeND, 10.11 .2021 


\section{TU Clausthal

\section{Research on nuclear waste management until 2016}

- Societal / political conflicts

- Scientific institutions, scientists and funding mechanismes often perceived as actors in conflicts

- Often questioned: Role of "the" science

\begin{tabular}{|c|c|}
\hline Pure Scientist & Issue Advocate \\
\hline Science Arbiter & $\begin{array}{c}\text { Honest Broker of } \\
\text { Policy Alternatives }\end{array}$ \\
\hline
\end{tabular}




\section{TU Clausthal

Request for transdisciplinary (TD) research ....

"There is the necesssity for a supplementary transdisciplinary research association acting independently, neutral and holistically on the basis of internationally recognised competence in order to provide a constructive societal contribution."

Commission on the Storage of High-Level Radioactive Materials, 2016 
... and ideas about shaping

the research and funding "landscape"

- at the implementing organisation

- at the regulatory authority

- at societal bodies engaged in the site selection procedure

- Independent basic research

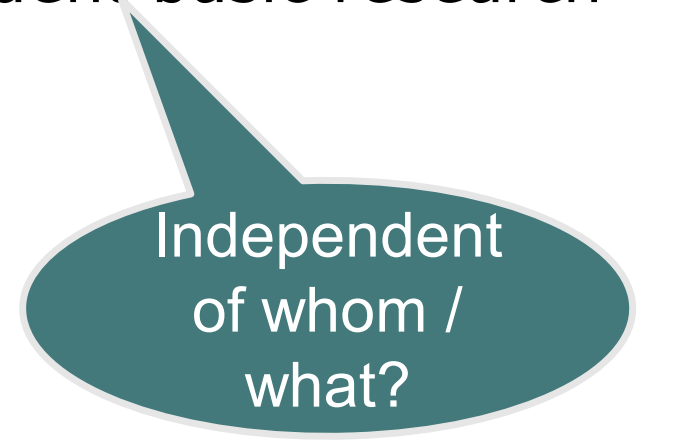

Commission on the Storage of High-Level Radioactive Materials, 2016 


\section{TU Clausthal \\ $\boldsymbol{E T H z u ̈ r i c h ~}$}

\section{Thus: Basis for TRANSENS application (until 2019)}

Transdisciplinary research on nuclear waste management in Germany

- Independent of actors in the site selection procedure

- Funding by Federal Ministry for Economic Affairs and Energy / Ministry for Science and Culture of Lower Saxony

$\rightarrow$ application-orientated basic research

- Areas of tension including:

- Co-production in parallel to ongoing site selection procedure

- Basic research vs. TD research

- "Funding logic" vs. co-design 


\section{TU Clausthal \\ ETHzürich \\ Transdisciplinary (TD) research in literature}

\begin{tabular}{|c|c|c|c|c|}
\hline $\begin{array}{l}\text { Overstepping } \\
\text { and integrating } \\
\text { disciplinary } \\
\text { paradigms }\end{array}$ & $\begin{array}{l}\text { Participative } \\
\text { research }\end{array}$ & $\begin{array}{l}\text { Orientating at } \\
\text { lifeworld } \\
\text { problems }\end{array}$ & $\begin{array}{l}\text { Universal unity } \\
\text { of knowledge }\end{array}$ & Represented by \\
\hline$X$ & $X$ & & & $\begin{array}{c}\text { Defila \& Di Giulio 1999, } \\
\text { Lawrence } 2004\end{array}$ \\
\hline$X$ & $X$ & $X$ & & $\begin{array}{c}\text { Häberli \& Grossebacher- } \\
\text { Manuy } 1998, \text { Klein et al. } \\
\text { 2001, Jahn } 2005\end{array}$ \\
\hline$x$ & & $X$ & & $\begin{array}{c}\text { Mittelstrass 1992, 1996, } \\
\text { Scheringer \& Jäger } \\
\text { 1998, Jantsch 1972, } \\
\text { Gibbons et al. } 1994\end{array}$ \\
\hline$X$ & & $x$ & $x$ & $\begin{array}{c}\text { Kokelmans } 1979, \\
\text { Nicolescu } 1996\end{array}$ \\
\hline
\end{tabular}




\section{TU Clausthal}

\section{EHHzürich}

\section{TRANSENS: TD according to application text}

- Reflexive, integrative und method-driven scientific prinziple aiming at the solution of a societal problem and related scientific challenges

- Central: Integration of non-specialists and actors from the realm of practice into research processes accounting for their knowledge bodies, values and expectations

- Only to a limited extent „intervening" („transformative”)

- Distance to site selection procedure, but observation and scientific evaluation where appropriate 


\section{TU Clausthal \\ EHzzürich}

\section{TRANSENS: "funding logic" vS. co-design}

Theme corridor:

- Constituted and defined by a research question

- Choice and width of themes subject to changes during the research process

- Space for communication, cooperation und agreement

- Agreement about specific research questions, topics and methods even at advanced project stages

$>$ Cf. e. g. presentation "Transdisciplinary research on repository safety" 


\section{TU Clausthal \\ EHHzürich}

\section{Four theme corridors and more}

- HAFF - Capacity to act and flexibility in a reversible procedure

- SAFE - Stakeholder perspectives on the safety case

- TRUST - Trust in a context of technology, uncertainties and complexity

- DIPRO - Dialogues and process design

- Education and vocational training (EDU)

- Accompanying formative research (Research on transdisciplinarity) 


\section{Our TD partners}

Selection dependent on research topic / question and stage

- Actors from the realm of practice (from Germany and abroad)

- Standing groups:

Citizen Working Group (AGBe) and DIPRO accompanying group (DBG) (i.e. no specialists, no lobbyists, no stakeholders)

$\rightarrow$ We research jointly with civil society representatives who are not directly "affected" (e. g. by the site selection procedure). 


\section{TU Clausthal \\ $\boldsymbol{E T H} z$ zürich}

Citizen Working Group (AGBe): Research experience

- Multi-step selection / recruitment process

- September 2020 - inaugural meeting

- Working basis

- Expectations

- Feedback

- Transdisziplinarity - What is this exactly? 


\section{TU Clausthal

Citizen Working Group (AGBe): Research experience

- Our input in various formats

- Learning curve - change of perspective - example

- Communication

- Status quo

- Expectation of hope

- Your feedback 


\section{TU Clausthal}

\section{After two years of research:}

- Learning process under pandemic conditions

- In parallel: Progress of site selection procedure: Observation / scientific evaluation ...

- ... but TRANSENS is a research project and does not act in the process

(notwithstanding activities of TRANSENS scientists in different roles)

- Results: Cf. ensuing presentations (and also presentations in other safeND sessions and workshops) 


\section{TU Clausthal}

\section{Conclusions}

- Strong need for learning, flexibility and adaptivity

- TD understanding

- Positioning in theme corridors - new understanding of co-design

- Choice of methods and partners (evolution / adaption)

- Application-orientated transdisciplinary research in parallel with ongoing site selection procedure

$>$ Variety of methods and (evolving) partnerships

$>$ Important (interim) results

$>$ Innovative types of partnerships and of TD research (?) 


\section{Thank you for your attention! Questions? Comments?}

Gefördert durch:

Bundesministerium
für Wirtschaft
und Energie

aufgrund eines Beschlusses des Deutschen Bundestages
Gefördert im

Niedersächsischen Vorab der Volkswagenstiftung

$$
\begin{aligned}
& \because: \text { VolkswagenStiftung } \\
& 0
\end{aligned}
$$

Förderkennzeichen: 02E11849A-J
口按回

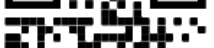
int:1 口ista

www.transens.de 